\title{
Multilobed Supernumerary Teeth with Talon: Pioneer Case Report
}

\author{
ROSY ARORA, NIKHIL MARWAH, MAHESH GOEL, SAMIR DUTTA
}

\section{ABSTRACT}

A rare case report of a multi-lobed supernumerary tooth having talon cusp is being reported. The tooth was extracted to correct the existing malocclusion and a complete radiographic and histological analysis of the extracted tooth was done to confirm the clinical finding of supernumerary tooth with incomplete lobes associated with talon cusp exhibiting pulpal extension.

\section{Contact Author}

Dr. Nikhil Marwah

E-mail : dr_nikhilmarwah@redifmail.com

Keywords: Supernumerary tooth, Talon cusp

$\mathrm{T}$ alon cusp is defined as an accessory cusp-like structure projecting from the lingual surface of a primary or permanent anterior tooth and extending at least half the distance from the cemento-enamel junction to the incisal edge(1). The first case was reported by Mitchell in 1892 on the lingual surface of a maxillary central incisor, who described it as "a process of horn like shape curving from the base downward to the cutting edge"(2). The term talon cusp was coined because of its resemblance to an eagle's talon in shape(3).

A review of literature suggests that the talon cusp has a striking predilection for the maxilla over the mandible with the majority of the cases occurring in maxillary anterior teeth(4). The occurrence of the talon cusp in a supernumerary tooth is extremely rare with only three cases reported till now. One of

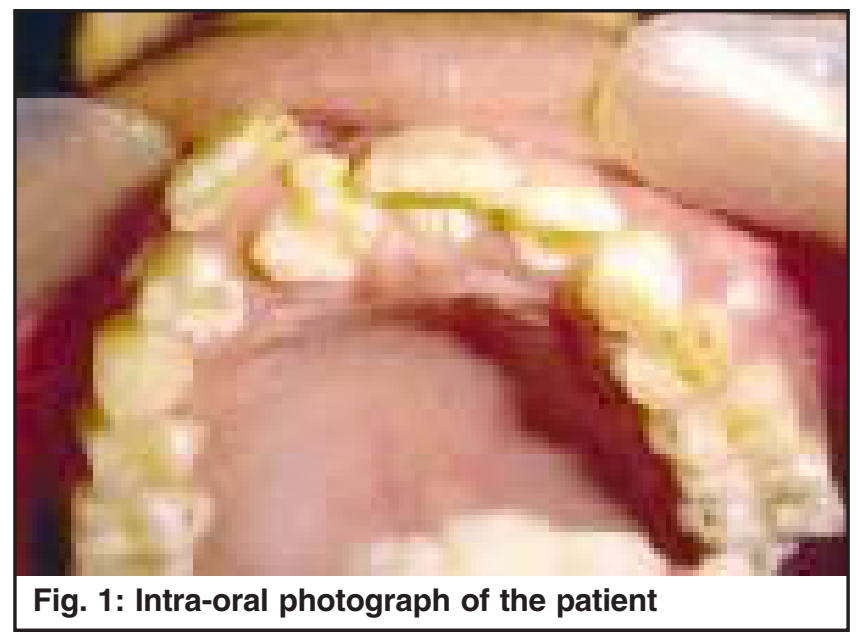

the first cases of talon cusp on a maxillary multi-lobed supernumerary tooth is being reported here.

\section{Case Report}

A 12- year old girl presented with the chief complaint of irregular teeth. Intraoral examination revealed a normal dentition and a supernumerary tooth present on the palatal aspect of maxillary right central incisor (Fig. 1). The supernumerary tooth had a cusp on the labial side and the palatal aspect had three incompletely developed lobes. Intraoral, periapical and occlusal radiographs were taken to confirm the diagnosis of a supernumerary tooth with multiple lobes associated with talon cusp.

Since the tooth was causing malocclusion, it was extracted under local anesthesia. The extracted tooth was preserved in $10 \%$ formalin. The respective cervicoincisal, mesio-distal, labio-lingual dimensions of the labial cusp were $7.5 \mathrm{~mm}, 3 \mathrm{~mm}, 3 \mathrm{~mm}$; the mesio-lingual lobe were $7 \mathrm{~mm}, 3 \mathrm{~mm}, 2.5 \mathrm{~mm}$; middle lobe were $4 \mathrm{~mm}$, $3 \mathrm{~mm}, 4 \mathrm{~mm}$ and the distolingual lobe were $6.5 \mathrm{~mm}$, $3 \mathrm{~mm}, \quad 3 \mathrm{~mm}$. The morphology of the root showed that the tooth was in rotated position in the arch with the labial aspect

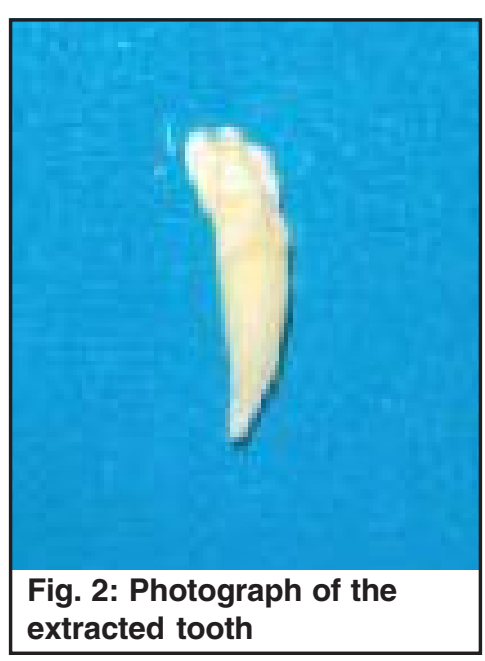


lying palatally and vice versa (Fig. 2). The tooth was radiographed from the labial and proximal aspects and the radiographs showed an extension of the pulp tissue into the accessory cusp (Fig. 3). Labio-lingual sections of the tooth were prepared and examined histologically by electron microscope to confirm pulpal extension into the talon cusp (Fig. 4).

\section{Discussion}

Talon cusp is a rare dental anomaly, which arise during the morpho-differentiation stage of

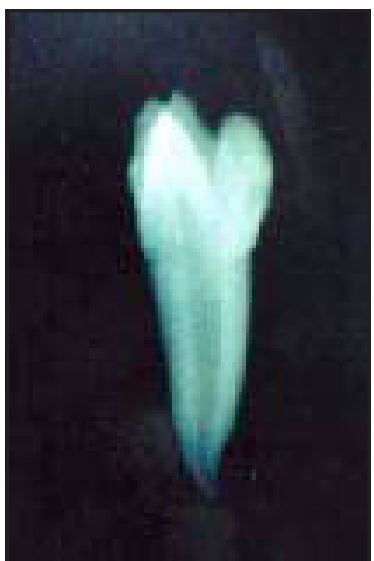

Fig. 3: Radiograph of the supernumerary tooth after extraction tooth development. It has been suggested that the accessory cusp has a multifactorial etiology combining both genetic and environmental factors. It may occur due to hyperactivity of the dental lamina and therefore, a supernumerary tooth can be expected(1,5). There are reports of the concurrence of the talon cusp with an impacted mesiodens, a complex odontome and dens evaginatus(1,6,7). The anomaly also appears to be more prevalent in patients with RubinsteinTaybi syndrome, Mohr syndrome and Sturge-Weber Syndrome $(8,9,10)$.

It had been reported that in $92 \%$ of the cases the cusp was found in the maxillary anterior teeth (lateral incisors followed by central incisors and canines). Talon cusps of supernumerary teeth are extremely rare(4). Salama et al (1990) reported two cases of talon cusp on supernumerary teeth and later, another case of talon cusp was reported by Nadkarni et al $(5,11)$. But no case of talon cusp on multi-lobed supernumerary teeth has been reported so far.

Several reports indicate that talon cusps are composed of normal enamel, dentin and pulp $(3,4)$. Others have ruled out the presence of pulpal extension on the basis of histological and microscopic examination $(5,6)$. In our cases, radiographs indicated the presence of the pulp horn in the talon cusp, which was confirmed by examining the histological sections of the tooth under electron microscope.

Clinical problems that may arise because of a talon cusp include compromised aesthetics, occlusal interference, carious developmental grooves, displacement of teeth, periodontal problems, irritation of the tongue and diagnostic problems. On the unerupted tooth, a talon cusp may be mistaken for a supernumerary tooth leading to unnecessary surgical intervention $(4,7)$. Therefore, it is desirable to evaluate and treat the talon cusp soon after eruption to avoid clinical problems. The management of talon cusp varies with the circumstances

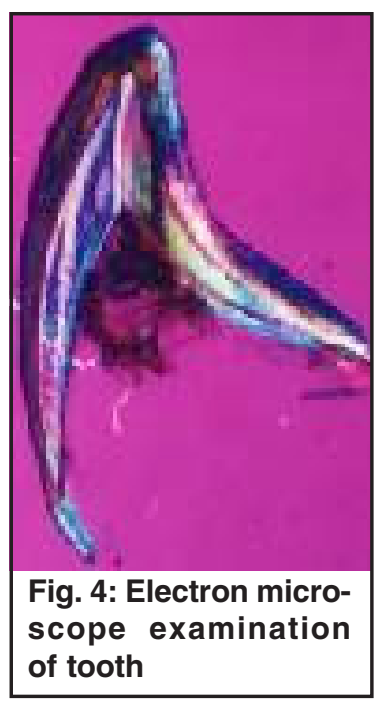

of the individual case. The treatment strategies are gradual reduction with fluoride application as desensitizing agent, single appointment reduction with or without pulp therapy, sealant application in the dental grooves and the partial reduction with composite camouflage $(12,13,14)$.

In the case reported here, since the tooth was causing malocclusion, extraction was the treatment of choice. Presently, the patient is undergoing orthodontic treatment for diastema closure and tooth alignment. Therefore, early recognition is important so that intervention can be done at initial stage itself.

\section{THE AUTHORS}

\section{Dr. Rosy Arora}

MDS

Sr. Lecturer

Dept. of Pedodontics and Preventive Dentistry,

Gyan Sagar Dental College,

Banur, Punjab

\section{Dr. Nikhil Marwah}

MDS

Asst. Professor

Dept. of Pedodontics and Preventive Dentistry

Govt. Dental College

Rohtak (Haryana)

E-mail: dr_nikhilmarwah@rediffmail.com

\section{Dr. Mahesh Goel}

MDS

Asst. Professor

Dept. of Oral \& Maxillo-facial Surgery

Govt. Dental College

Rohtak (Haryana)

E-mail: dr_nikhilmarwah@rediffmail.com

\section{Dr. Samir Dutta}

MDS

Professor \& Head

Dept. of Pedodontics and Preventive Dentistry

Govt. Dental College

Rohtak (Haryana)

\section{References}

1. Davis PJ, Brook AJ. The professional of talon cusp; diagnosis, clinical features, associations and possible etiology. Br Dent $J$ 1985;159:84-85.

2. Mitchell WH. Case report. Dent Cosmos 1892;34:1036.

3. Mellor JK, Ripa LW. Talon cusp; a clinically significant anomaly. Surg 1970;29:225-28

4. Hatlab FN, Yassin OM, Al-Nimri. Talon cusp in permanent 
dentition associated with other dental anomalies: a review of literature and reports of seven cases. J Dent Child 1990;57:14749.

5. Salama FS, Hanes CM, Hanes PJ, Ready MA. Talon cusp: a review and two case reports on supernumerary primary and permanent teeth. $J$ dent Child 1990;57:147-49.

6. Natkin E, Pitts DL, Worthington P. A case of talon cusp associated with other dental abnormalities. J Endod 1983;9:491-495

7. Mader CL. Mandibular talon cusp. J Am Dent Assoc 1981;103: 244-246.

8. Chen RJ, Chen HS. Talon cusp in primary dentition. Oral surgery Oral Med Oral Radiol Endod 1986;62:67-72.
9. Gardner DG, Girgis SS. Talon cusp: a dental anomaly in the Rubinstein-Taybi syndrome. Oral Surgery 1979;47:519-521.

10. Goldstein E, Mendina JL. Mohr syndrome or oral facial digital II: report of two cases. J Am Dent Assoc 1974;89:377-382.

11. Nadkarni Um, Munshi A, Damle SG. Unusual presentation of talon cusp: two case reports. Int J Ped Dent 2002;12:332-335.

12. Myers CL. Treatment of a talon cusp-incisor: report of a case. $J$ Dent Child 1980;47:43-45.

13. Richardson DS, Knudson KG. Talon cusp: a preventive approach to treatment. J Am Dent Assoc 1985;110: 60-62.

14. Pitts DL, Hall SH. Talon cusp: Orthodontic and endodontic considerations. J Dent Child 1983;50:364-368. 